\title{
VELOCITIES OF SLOW MIGRATION OF SEISMIC ACTIVITY IN CIS-BAIKAL REGION
}

\author{
A. V. Novopashina, V. A. San'kov \\ Institute of the Earth's Crust, Siberian Branch of RAS, 664033, Irkutsk, Lermontov street, 128, Russia
}

Abstract: Three-dimensional space-time diagrams of «logarithm of total energy released by earthquakes» parameter, $\lg \mathrm{E}_{\text {sum }}$ are constructed for regions with stable concentrations of earthquake epicenters in Cis-Baikal region for a period from 1964 to 2002. Based on analyses of such diagrams, areas of slow migration of seismic activity are defined. Estimated are distances, time and velocities of slow migration in the range of the first kilometers - first dozen of kilometers per year.

Procedures of seismic data projection and construction of 3D diagrams are described in brief. A general scheme including contours of projection areas is proposed for the Pribaikalie (Fig. 1).

Three space-time diagrams are presented as examples of application of the above mentioned procedures. They are constructed for the Middle and Southern Baikal basins and the western part of the NE flank of the Baikal rift system (Fig. 2). Integrated analytical results are presented for all the diagrams which record earthquake migration within the Baikal rift system. We also present a scheme of the zone of slow migrations ranked by dominating velocities (Fig. 3 ) and a diagram of the migration velocity range.

We consider possible causes of slow migration of seismic activity at variable velocities: (1) slow deformation waves spreading in the crust, and (2) independent propagation of the deformation front along active faults.

Regulations of migration of strong earthquakes can be useful for definition of timelines and locations of future strong seismic events.

Keywords: earthquake, seismic activity, migration, velocity, deformation front, deformation wave.

Recommended by S.I. Sherman 20 April 2010

Novopashina A.V., San'kov V.A. Velocities of slow migration of seismic activity in Cis-Baikal region // Geodynamics \& Tectonophysics. 2010. V. 1. № 2. P. 197-203.

\section{СКОРОСТИ МЕДЛЕННЫХ МИГРАЦИЙ СЕЙСМИЧЕСКОЙ АКТИВНОСТИ В ПРИБАЙКАЛЬЕ}

\author{
А. В. Новопашина, В. А. Саньков \\ Институт земной коры СО РАН, 664033, Иркутск, ул. Лермонтова, 128, Россия
}

Аннотация: На базе анализа трехмерных пространственно-временных диаграмм параметра «логарифм суммарной выделившейся при землетрясениях энергии» $\left(\lg E_{\text {sum }}\right)$, построенных для районов стабильных концентраций эпицентров землетрясений за период 1964-2002 гг., на территории Прибайкалья выделены области, которым свойственны медленные миграции сейсмической активности. Определены расстояния, время и скорости медленных миграций, измеряемые первыми километрами - первыми десятками километров в год.

Кратко описана методика проецирования сейсмических данных и построения трехмерных диаграмм, приведена иллюстрационная схема Прибайкалья, содержащая контуры областей проецирования (рис. 1).

Представлены примеры пространственно временных диаграмм трех областей: Среднебайкальской впадины, Южно-Байкальской впадины, а также западной части северо-восточного фланга Байкальской рифтовой системы (рис. 2). Приведены обобщенные результаты анализа всех диаграмм, на которых зафиксированы мигра- 
ции землетрясений в пределах Байкальской рифтовой системы, схема зон медленных миграций, ранжированных по преобладающим скоростям, и диаграмма спектра скоростей миграций (рис. 3).

Рассматриваются возможные причины, вызывающие медленные миграции сейсмической активности с различной скоростью: (1) медленные деформационные волны, распространяющиеся в земной коре, (2) самостоятельное продвижение фронта деформаций вдоль активных разломов.

Закономерности миграций землетрясений в сейсмоактивных областях могут быть использованы для определения времени и места будущих сейсмических событий.

Ключевые слова: землетрясение, сейсмическая активность, миграция, скорость, фронт деформаций, деформационная волна.

\section{ВвеДЕНИЕ}

Максимумы сейсмической активности в пределах сейсмоактивных областей испытывают пространственные и временные изменения, которые в общем случае можно определить как миграции. Согласно представлениям А.В. Викулина, миграция скоплений эпицентров землетрясений разной силы является пространственно-временной закономерностью сейсмического процесса, под которым следует понимать совокупность землетрясений протяженного региона, рассматриваемую в пространстве и во времени с учетом взаимодействия их очагов [Викулин, 2003]. Скорости миграций сейсмической активности, совокупностей и отдельных сейсмических событий могут меняться в широких пределах - от долей км/год до первых сотен км/год. Например, продольная миграция сильнейших землетрясений сейсмической зоны Северных Курил - Камчатки происходит со скоростью $\mathrm{V}=4 \pm 1$ км/год, поперечная миграция событий, направленная вкрест простирания береговой линии, - со скоростью 0.3-0.4 км/год [Викулин, 2003]. Очаги сильнейших землетрясений северо-западной окраины Тихого океана группируются в цепочки, в пределах которых они мигрируют в направлении с юго-запада на северо-восток со скоростью, равной $\mathrm{V}=250 \pm 30 \mathrm{\kappa m} / г о д$ [Вилькович, Шнирман, 1982; Викулин, 2003]. По мнению многих исследователей, скорость таких миграций определена скоростью распространения медленной деформационной волны в литосферном пространстве, стимулирующей возникновение очагов землетрясений [Быков, 2005; Николаевский, 2005; Шерман, 2005]. Широкий спектр скоростей деформационных волн, согласно работе [Быков, 2005], обусловлен большим набором источников и механизмов миграций. Для территории Центральной Азии, включающей Прибайкалье, скорости сейсмической активизации разломов различных рангов, которые интерпретируются как отражение продвижения деформационных волн, составляют первые километры - десятки километров в год [Шерман, 2005].

В данной работе для оценки скоростей миграций сейсмической активности используются пространственно-временные миграции максимумов параметра эпицентрального поля - логарифма суммарной выделившейся при землетрясениях энергии $\left(\operatorname{LgE}_{\text {sum }}\right)$. Сделана попытка получить статистически значимый набор скоростей миграций, характери- зующих сейсмический процесс в Байкальской рифртовой системе.

\section{МЕТОДИКА ИССЛЕДОВАНИЯ МИГРАЦИОННЫХ ПРОЦЕССОВ}

Наглядным способом представления сейсмического процесса, позволяющим выявить миграции сейсмической активности вдоль заданного направления и определить их скорости, является пространственно-временная развертка [Ризниченко, 1958], подразумевающая построение трехмерных пространственно-временных диаграмм параметра

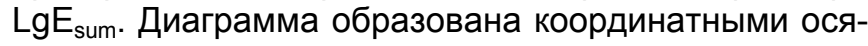
ми: «направление», «время», «параметр $\operatorname{LgE}_{\text {sum». }}$ Отношение проекции осей максимумов используемого параметра на оси расстояния (L) и времени (T) определено скоростью прохождения миграции сейсмической активности (L/T).

Эпицентральное поле землетрясений Байкальской рифтовой системы (БРС) характеризуется наличием протяженных линейных скоплений эпицентров, направленных вдоль основных рифтовых структур. Для таких скоплений была задана область проецирования сейсмических данных (рис. 1), представляющая собой полосу, разделенную прямоугольными ячейками размером $\Delta \mathrm{L}=0.1^{\circ}$. Простирание полос максимально приближено к осям концентраций эпицентров, а ширина и длина определены размером областей сгущения очагов. Параметр $\mathrm{LgE}_{\text {sum }}$ получен по данным БФ ГС СО РАН за инструментальный период 1964-2002 гг. для представительных землетрясений (энергетический класс К $\geq 8$ ), энергия которых суммировалась за период времени $\Delta \mathrm{T}=1$ месяц в пределах ячеек проецирования. Значения $\mathrm{LgE}_{\text {sum }}$ интерполировались в пределах значений $3 \Delta \mathrm{T}$ × $3 \Delta \mathrm{L}$ методом линейной интерполяции. Используемая методика позволяет выделять медленные миграции сейсмической активности, скорости которых приходятся на часть спектра скоростей, измеряемых километрами - первыми десятками километров в год.

\section{РЕЗУЛЬТАТЫ ИССЛЕДОВАНИЙ}

Анализ полученных диаграмм показал, что существуют четко выраженные продольные миграционные последовательности максимумов сейсмической активности, проходящие вдоль некоторых полос концентраций эпицентров. Зачастую миграции 


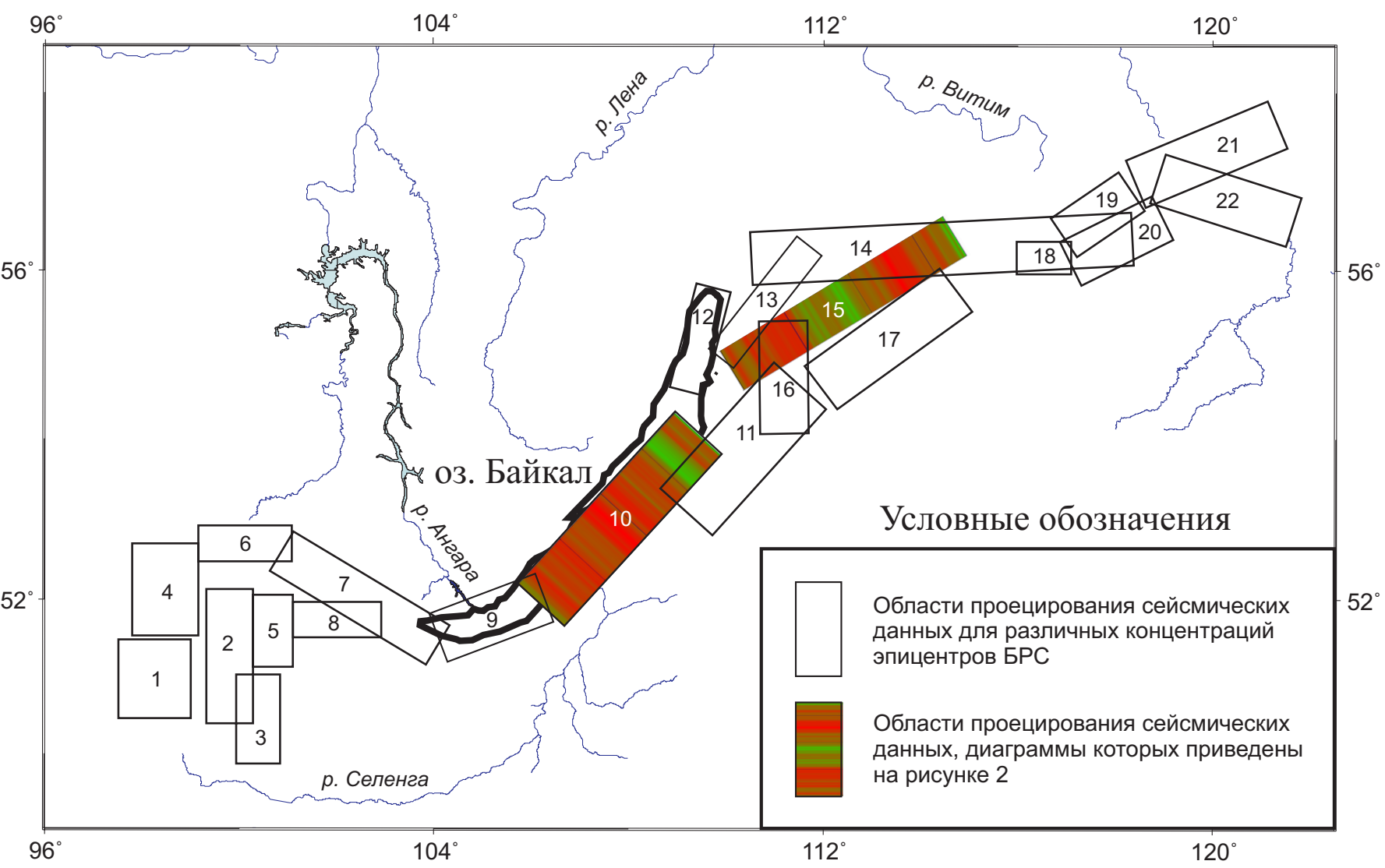

Рис. 1. Области проецирования сейсмических данных в Прибайкалье.

Fig. 1. Areas of seismic data projection in Cis-Baikal region.

носят циклический характер и могут быть отнесены к маятниковым [Ружич, Хромовских, 1989; Шерман, 2005], иногда направлены в одну сторону (односторонние по [Ружич, Хромовских, 1989]). Цепочки максимумов используемого параметра образованы как слабыми сейсмическими событиями $(11.5 \geq \mathrm{K} \geq 8)$, так и сильными (15.9 $\geq К \geq 11.5)$. В основном миграции проявляются в областях с относительно высоким числом слабых событий. На рис. 2 приведены примеры диаграмм для сейсмоактивных областей БРС: района Среднебайкальской впадины (рис. 2, $A)$, соответствующей области проецирования 10 на рис. 1, и одного из районов северо-восточного флланга БРС, соответствующего области проецирования 15 на рис. 1 (рис. 2, Б). Анализ двадцати двух диаграмм показал, что отдельным зонам свойственны определенные моды скоростей миграций (рис. 3, врезка). Скорости меняются в узком интервале в пределах одной сейсмоактивной зоны и могут сменить диапазон значений при переходе в соседнюю зону.

Большинству сейсмических зон юго-западного и северо-восточного флангов Байкальского рифта свойственны скорости до 20 км/год (рис. 3). Мода

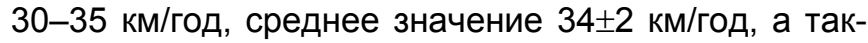
же скорости 35-70 км/год характерны для района Среднебайкальской впадины. В районе Южно-Байкальской впадины зафиксированы миграции, прохо- дящие со скоростью 15-20 км/год, некоторые из них накладываются на тренд $3.4 \pm 0.4$ км/год, представляющий собой закономерное длительное (39 лет) смещение сейсмического процесса с северовостока на юго-запад, включающее землетрясения энергетических классов $15.9 \geq \mathrm{K} \geq 14$ (рис. 4).

Длины зафиксированных миграционных цепочек, обусловленные блочной делимостью земной коры и соответствующие длинам сегментов активных разломов [Мишарина, Солоненко, 1990], ответственных за генерацию землетрясений, принимают характер-

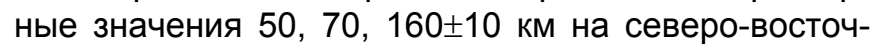

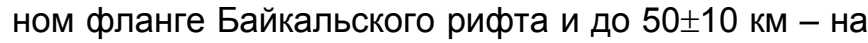
юго-западном. В центральной части значения длин таких цепочек самые различные: 30-100, с преобладанием длины траекторий до 50 км ( \pm 10 км).

\section{ОБСУЖДЕНИЕ РЕЗУЛЬТАТОВ}

Полученные в результате проведенного исследования данные о скоростях миграции сейсмической активности в БРС не противоречат данным ранее проведенных исследований. Так, скорости медленных продвижений эпицентров землетрясений вдоль активных разломов (2-30 км/год), рассчитанные в работе [Шерман, Горбунова, 2008] для Центральной Азии, близки к скоростям миграций сейсмической активности, полученным нашим ме- 
A

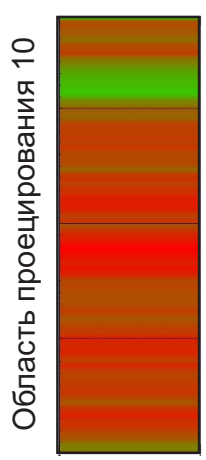

Б
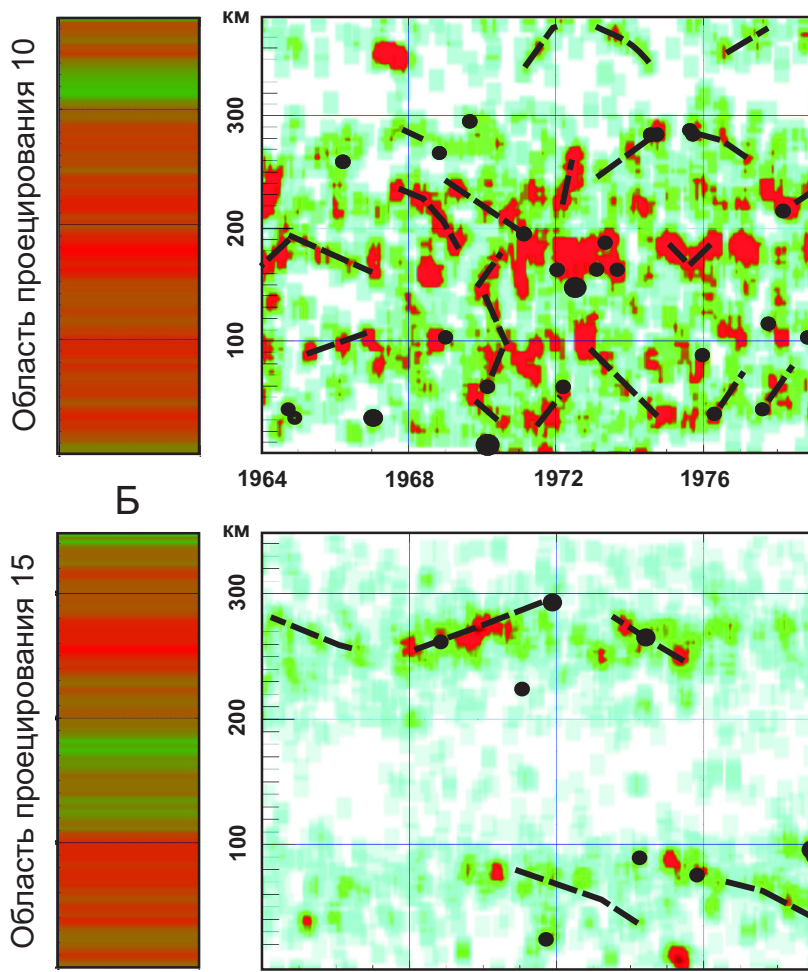
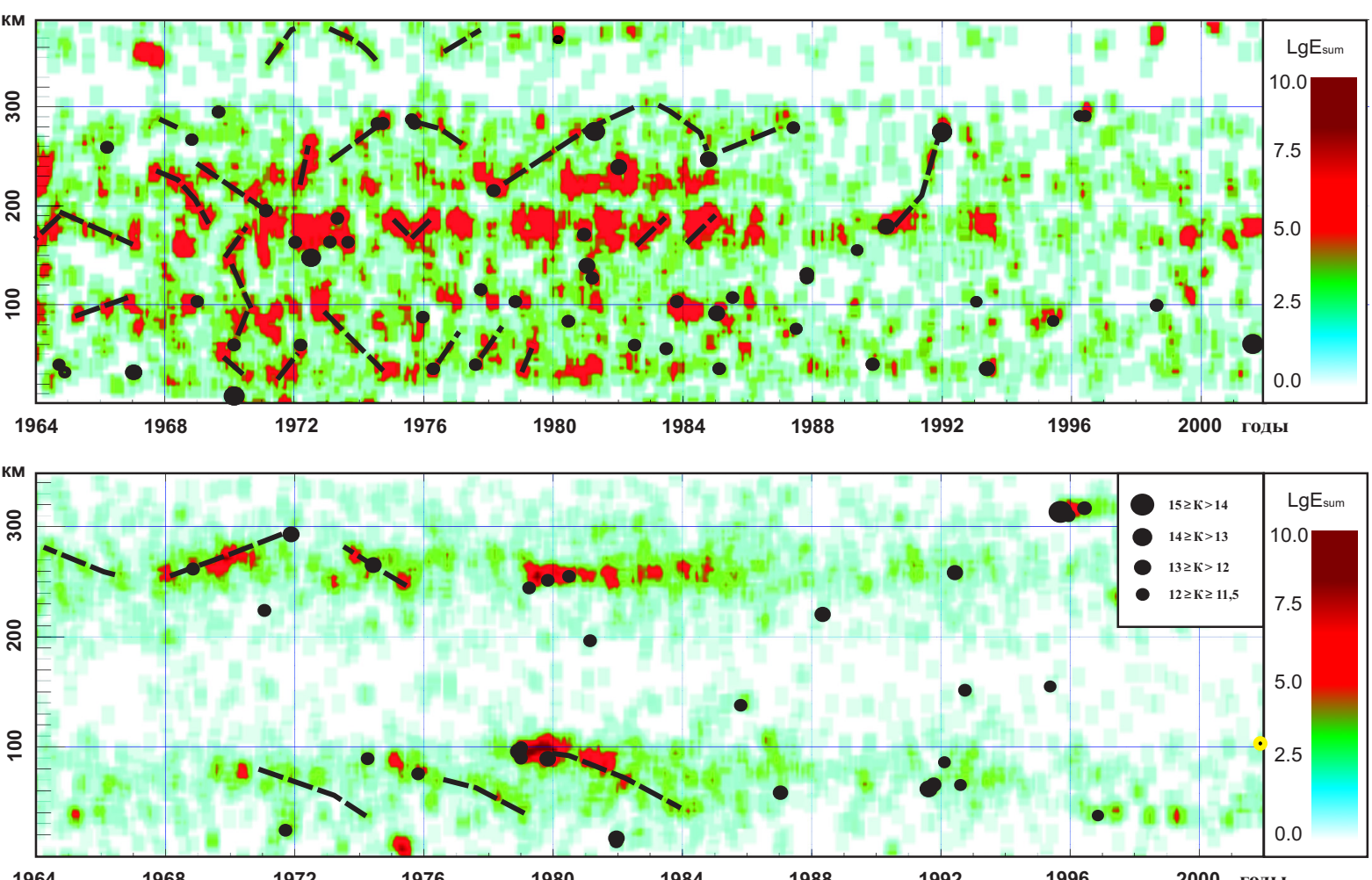

Рис. 2. Примеры пространственно-временных диаграмм, включающих зоны миграций землетрясений: $A$ - зоны проецирования 10 (район Среднебайкальской впадины). Простирание полосы проецирования СВ-Ю3 (азимут $73^{\circ}$ ); 5 - зоны проецирования 15 (район Верхнеангарской впадины). Простирание полосы проецирования СВ-Ю3 (азимут 58); пунктирными линиями обозначены условные оси максимумов параметра $\mathrm{Lg} \mathrm{E}_{\text {sum. }}$.

Fig. 2. Sample space-time diagrams, including zones of earthquake migration. $A$ - projection zone \#10, the Middle Baikal basin area. Strike of the projection line: NE-SW, azimuth $73^{\circ}$. B - projection zone \#15 (the Upper Angara basin area). Strike of the projection line: NE-SW, azimuth $58^{\circ}$. Dashed lines show conditional axes of maximum values of parameter $\mathrm{LgE}_{\text {sum. }}$.

тодом. Скорость миграции сильных землетрясений Южно-Байкальской впадины приходится на диапазон значений 2-6 км/год, который характерен для сильнейших землетрясений Средней Азии [Никонов, 1975]. Исследования более высокоскоростных миграций сейсмического процесса (выше 100 км/год), которые, скорее всего, также присутствуют в Прибайкалье [Саньков и др., 1998], требуют более детальной временной развертки пространственновременных диаграмм.

Различия средних скоростей миграций сейсмической активности между флангами и центральной частью БРС в 2-3 раза в пользу последней могут быть объяснены существенными различиями в концентрированности и интенсивности сейсмического процесса между этими структурами. Ширина зоны сейсмогенных деформаций в центральной части БРС ограничена шириной Байкальской впадины, внутри которой средний уровень сейсмической активности постоянно высок. Центральная и южная части Байкальской впадины являются наиболее древним звеном БРС [Логачев, 2001]. В соответствии с этим степень разрушения земной коры и «проработанность» зоны Обручевского разлома относительно наиболее высоки, а их прочность - наименьшая в БРС.

Миграции сейсмической активности или миграции землетрясений как отражение изменения напряженно-деформированного состояния земной коры интерпретируются по-разному. Распространенной является точка зрения о волновой природе таких миграций [Быков, 2005; Николаевский, 2005; Шерман, 2005]. Наличие достаточно широкого спектра скоростей миграций, проявляющихся одновременно в различных частях рифтовой системы (см. рис. 3), не позволяет использовать для их объяснения идею прохождения единой деформационной волны через всю зону. Одним из редких проявлений такого процесса, возможно, служит меридиональная миграция сейсмической активности, отмеченная в работе [Саньков и др., 1998]. Вместе с тем широко известны триггерные эффректы сильных землетрясений (stress transfer), когда сопоставимые по энергии события следуют друг за другом с небольшим интервалом (годы - первые десятки лет) [Chery, 2001]. При этом предполагается, что передача напряжений на большие расстояния может происходить быстро в результате упругой реакции верхней коры [Chery, 2001] и замедленно в результате вязко-упругой реакции нижней коры и верхней мантии 


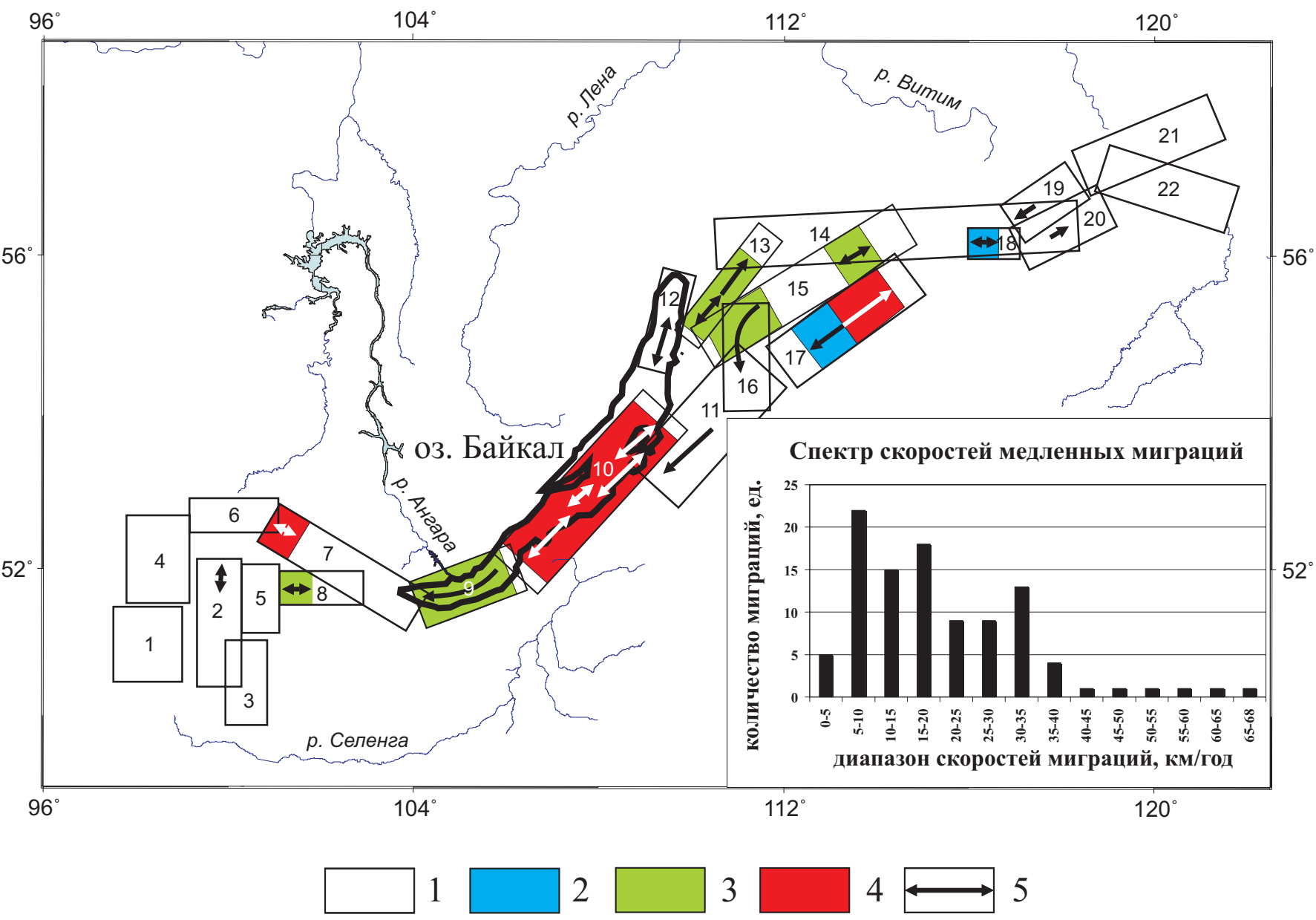

Рис. 3. Зоны медленных миграций сейсмичности Байкальской рифртовой системы. 1 - области проецирования сейсмических данных; 2 - зоны миграций с преобладанием скоростей 5-10 км/год; 3 - зоны миграций с преобладанием скоростей 10-20 км/год; 4- зоны миграций с преобладанием скоростей $30 \pm 2$ км/год и выше; 5 - направление миграций. На врезке - спектр скоростей миграций Прибайкалья.

Fig. 3. Zones of slow migration of seismicity in the Baikal rift system. 1 - areas of seismic data projection. Zones of earthquake migration by dominating velocities: 2 - from 5 to $10 \mathrm{~km}$ per year, 3 - from 10 to $20 \mathrm{~km}$ per year, $4-30 \pm 2 \mathrm{~km}$ per year and above; 5 - direction of migration. Inserted is a scheme of the range of velocities of earthquake migration in Cis-Baikal region.

[Pollitz, 2003]. Землетрясения меньшей силы также способны приводить к изменениям напряженного состояния в соответствующей их энергии области. Таким образом, в коре может существовать огромный набор источников возмущений, распространяющихся с различными скоростями на различные расстояния. Потенциально их прохождение может фиксироваться в виде миграций сейсмического процесса с широким спектром скоростей.

В пределах сейсмоактивных зон, генетически связанных с активными разломами и их ансамблями, миграция сейсмической активности может отражать медленное продвижение фронта деформаций по механизму, предлагаемому в работе [Нелинейная механика..., 2007]. Толчок к продвижению такого фронта может быть задан превышением напряжениями прочности материала на каком-либо участке. Скорость миграции будет зависеть от прочностных свойств зоны, вдоль которой она распространяется. Можно согласиться с авторами [Бы- ков, 2005; Шерман, 2009], что такие процессы также относятся к волновым. Таким образом, миграция фронтов деформаций может быть спровоцирована как триггерными эфффектами, так и динамикой процесса деформации земной коры в Байкальской рифтовой системе.

Полученное распределение скоростей медленных миграций сейсмической активности, по-видимому в силу недостаточной статистики, не может пока дать ответа на вопрос, существуют ли характерные значения этого параметра, хотя логически легко допустить, что, наряду с интенсивностью выделения сейсмической энергии, скорость миграций будет зависеть от их природы и строения геологической среды.

\section{ЗАКЛЮЧЕНИЕ}

Результаты проведенных исследований позволили зафиксировать медленные односторонние и 
KM

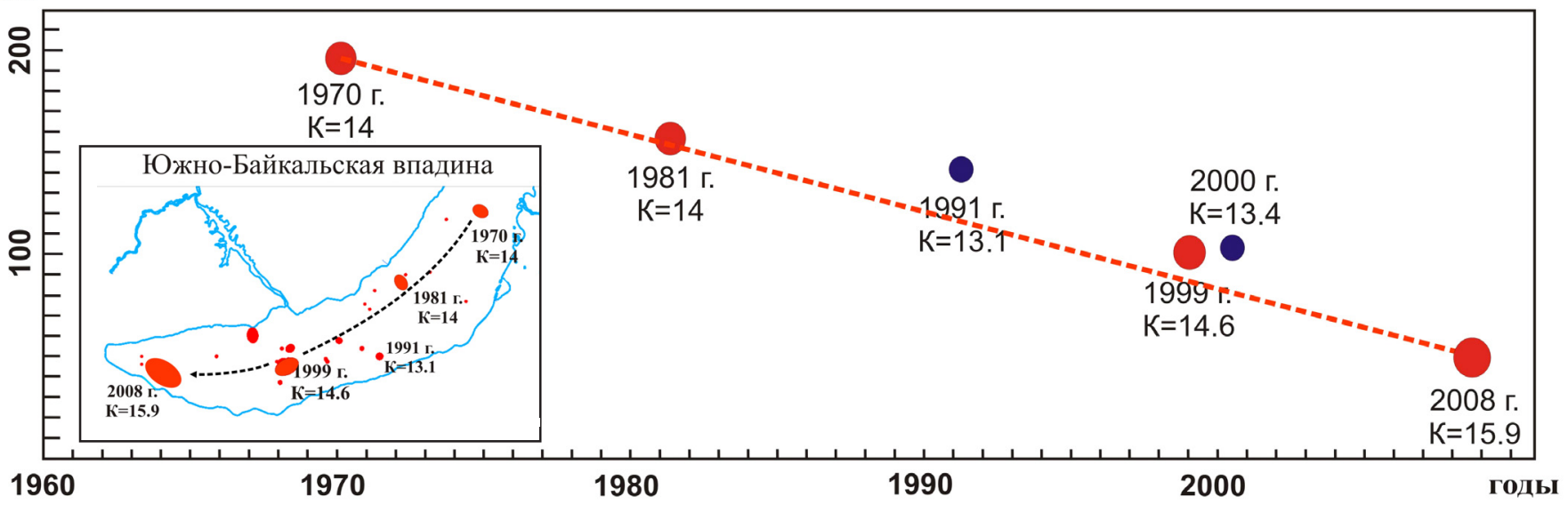

Рис. 4. Пространственно-временная диаграмма сильных событий зоны проецирования 9 (район Южно-Байкальской впадины). Простирание полосы проецирования СВ-Ю3 (азимут $79^{\circ}$ ).

Fig. 4. Space-time diagram of strong earthquakes for projection area \#9, the Southern Baikal basin area. Strike of the projection line: NE-SW, azimuth $79^{\circ}$.

маятниковые миграции сейсмической активности, свойственные сейсмоактивным зонам БРС. Используемая методика дала возможность выделить часть спектра скоростей, определенную на интервале от первых километров до первых десятков километров в год. Скорости миграций на флангах Байкальского рифта принимают, за некоторым исключением, значения в диапазоне 10-20 км/год, а в центральной его части в 2-3 раза больше. Последнее связывается с более высоким уровнем нарушенности земной коры центральной части БРС по отношению к ее флангам. Наряду с быстрыми миграциями, выделяющимися по данным о слабых землетрясениях, в Южно-Байкальской впадине выявлены медленные миграции сейсмической активности, связанные с сильными сейсмическими событиями.

Наличие достаточно широкого спектра скоростей и разных направлений миграций сейсмической активности в БРС в одни и те же периоды времени позволяет предполагать присутствие в коре большого количества источников, инициирующих продвижение фронтов деформаций. В качестве возможных механизмов медленных миграций сейсмической активности с различной скоростью могут рассматриваться медленные деформационные волны, распространяющиеся в земной коре, и самостоятельное продвижение фронта деформаций вдоль активных разломов, вызванное триггерным воздействием или определяемое собственно динамикой тектонического деформирования коры.

Дальнейшие исследования с применением других способов расчета скоростей миграций сейсмической активности дадут возможность увеличить статистику и выявить характерные для БРС и ее частей значения этого параметра. Возможность учитывать закономерности миграций сильных землетрясений сейсмоактивных областей вблизи социально значимых объектов может быть использована для определения времени и места будущих сильных сейсмических событий.

Работа выполнена при частичной поддержке РФФИ (проект № 08-05-98044), Программы РАН 16.8 и ИП СО РАН № 61.

\section{ЛИтЕРАТУРА}

Быков В.Г. Деформационные волны Земли: концепция, наблюдения и модели // Геология и геофизика. - 2005. - Т. 46, № 11. - С. 1176-1190.

Викулин А.В. Физика волнового сейсмического процесса. - Петропавловск-Камчатский: КОМСП ГС РАН, КГПУ, 2003. $152 \mathrm{C}$.

Вилькович E.B., Шнирман М.Г. Волны миграции эпицентров (примеры и модели) // Математические модели строения Земли и прогноза землетрясений. (Вычислительная сейсмология. Вып. 14). - М.: Наука, 1982. - С. 27-37.

Логачев Н.А. Об историческом ядре Байкальской рифтовой зоны // Доклады АН. - 2001. - Т. 376, № 4. - С. 510-513.

Мишарина Л.А., Солоненко А.В. Влияние блоковой делимости земной коры на распределение сейсмичности в Байкальской рифтовой зоне // Сейсмичность Байкальского рифта. Прогностические аспекты. - Новосибирск: Наука, 1990. - С. 70-78.

Нелинейная механика геоматериалов и геосред / Отв. ред. Л.Б. Зуев. - Новосибирск: Академическое изд-во «Гео», 2007. $235 \mathrm{c}$.

Николаевский В.Н. Математическое моделирование уединенных деформационных и сейсмических волн // Доклады АН. 1995. - Т. 341, № 3. - С. 403-405.

Никонов А.А. Миграция сильных землетрясений вдоль крупнейших зон разломов Средней Азии // Доклады АН СССР. 1975. - Т. 225, № 2. - С. 306-309.

Ризниченко Ю.В. Об изучении сейсмического режима // Изв. АН СССР. Сер. геофиз. - 1958. - № 9. - С. 1057-1074.

Ружич В.В., Хромовских В.С., Перязев В.А. Анализ глобальной пространственно-временной миграции очагов сильных землетрясений с геотектонических позиций // Инженерная геодинамика и геологическая среда. - Новосибирск: Наука, 1989. - C. 72-81.

Саньков В.А., Буддо В.Ю., Зуев Ф.Л. Монголо-Байкальская сейсмоактивная система как саморазвивающаяся диссипативная структура // Теория диссипативных структур в геологическом анализе: Материалы IV конференции по геологической синергетике. - Апатиты: Изд-во Кольского научного центра РАН, 1998. - C. 83-84.

Шерман С.И. Тектонофизический анализ сейсмического процесса в зонах активных разломов литосферы и проблема сред- 
несрочного прогноза землетрясений // Геофизический журнал. - 2005. - Т. 27, № 1. - С. 20-38.

Шерман С.И. Деструкция литосферы и ее реализация в разломообразовании и сейсмичности: разработка тектонофизической модели сейсмической зоны // Геодинамическая эволюция литосферы Центрально-Азиатского подвижного пояса (от океана к континенту): Материалы совещания. Вып. 7. - Иркутск: ИЗК СО РАН, 2009. Т. 2. - С. 67-70.

Шерман С.И., Горбунова Е.А. Волновая природа активизации разломов Центральной Азии на базе сейсмического монито- ринга // Физическая мезомеханика. - 2008. - Т. 11, № 1. C. $115-122$.

Chery J., Merkel S., Bouissou S. A physical basis for time clustering of large earthquakes // Bulletin of the seismological society of America. - 2001. - V. 91, № 6. - P. 1685-1693.

Pollitz F., Vergnolle M., Calais E. Fault interaction and stress triggering of twentieth century earthquakes in Mongolia // Journal of Geophysical Research. - 2003. - V. 108, № B10. - 2503. doi:10.1029/2002JB002375.

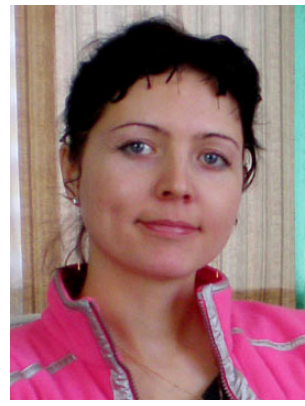

Новопашина Анна Владимировна, м. н. с.

Институт земной коры СО РАН

664033, Иркутск, ул. Лермонтова, 128, Россия

Тел. (3952)429534; e-mail: anek-sanek@mail.ru

Novopashina, Anna V., Researcher

Institute of the Earth's Crust, Siberian Branch of RAS

664033, Irkutsk, Lermontov street, 128, Russia

Tel. +7(3952)429534; e-mail: anek-sanek@mail.ru

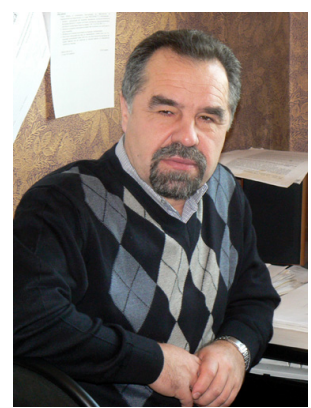

Саньков Владимир Анатольевич, канд. геол.-мин. наук, зав. лабораторией

Институт земной коры СО РАН

664033, Иркутск, ул. Лермонтова, 128, Россия

Тел. (3952)427903; e-mail: sankov@crust.irk.ru

San'kov, Vladimir A., Candidate of Geology and Mineralogy, Head of Laboratory

Institute of the Earth's Crust, Siberian Branch of RAS

664033, Irkutsk, Lermontov street, 128, Russia

Tel. +7(3952)427903; e-mail: sankov@crust.irk.ru 